\title{
A Literature Review of Human, Organization, Technology (HOT) - Fit Evaluation Model
}

\author{
Wilis Putri Hapsari ${ }^{1, *}$ Umar Abdul Labib ${ }^{2,}$ Haryanto Haryanto ${ }^{3,}$ Dhamar Widya \\ Safitri ${ }^{1}$
}

${ }^{1}$ Master of Educational Research and Evaluation, Graduate School, Universitas Negeri Yogyakarta, Indonesia

${ }^{2}$ Master of Biology Education, Faculty of Mathematics and Sciences, Universitas Negeri Yogyakarta, Indonesia

${ }^{3}$ Department of Educational Research and Evaluation, Graduate School, Universitas Negeri Yogyakarta, Indonesia

*Corresponding author. Email: wilisputri.2019@student.uny.ac.id

\begin{abstract}
An evaluation model that is used to evaluate the electronic service system came to prominence a decade ago with the appearance of Yusof 2007 article on Human, Organization, Technology (HOT) and Net Benefit specifically on health informatic systems. Since that time, the approach has attracted many researchers to use the framework in evaluating electronic system services in several sectors. This paper systematically examines cases of HOT fit evaluation model practices comport with the use of the evaluation model integrating the HOT fit component by reviewing 30 articles conducting the evaluation model. The data figured out by classifying the article onto the sector that had been criticised through the evaluation model by using the help of Atlas.ti software program. Evidence derived from this review to repudiate or substantiate many of the claims put both by critics of and advocates for evaluation model are presented as an agenda for future research on the future research. Further research is recommended to overcome the development of technological development.
\end{abstract}

Keywords: Hot-fit, Evaluation model, Review

\section{INTRODUCTION}

Evaluation is a movement to gather data crafted by something, which is then used to decide the correct option. In the meantime, a program is an arrangement that includes different units containing strategies and a progression of exercises that should be done inside a specific timeframe. The term assessment has related implications, each alluding to utilizing a few worth scales to strategy and program results. When all is said in done, the term assessment is inseparable from evaluation, ratting, and appraisal of words that express endeavors to investigate strategy brings about the units of significant worth. In a more explicit sense, assessment is worried about the creation of data about the worth or advantages of the approach result

Hence it tends to be reasoned that program assessment is a unit or unit of exercises that expects to gather data about the acknowledgment or usage of a strategy, happens in a persistent cycle, and happens in an association that includes a gathering of individuals for dynamic. A program is an arrangement that includes different units containing strategies and a progression of exercises that should be completed inside a specific timeframe to be actualized in the field. In the interim, program assessment expects to assemble data in regards to the execution of projects used to complete subsequent exercises or dynamic. Assessment or management exercises are planned to settle on choices or circle back to programs that have been actualized.

This model was proposed by Yusof MM [1][2] that the rationale for this model comes from the information system evaluation model by DeLone McLean [3]. This assessment model explains all the segments contained in the data framework itself, specifically people who survey the data framework regarding utilize identified with who utilizes it, preparing, experience, information, assumptions, perspectives to acknowledge and dismiss the framework. Associations that evaluate a framework from its hierarchical design and authoritative climate 
identified with arranging, the executives, framework control, the board uphold, financing. Innovation that surveys the framework quality, data quality and administration quality. These three factors are related to the dimensions of information system success, namely the quality system, information quality, service quality, system use, user satisfaction, and net benefit. Each of these elements is included in the HOT component. Human or human components include system development, system use, and user satisfaction. organizational components include structure and environment. Meanwhile, the technology component includes system quality, information quality, and service quality. this dimension is also linked to benefits or called net benefit.

These dimensions influence system quality, information quality, service quality which together tend to influence system use and user satisfaction. Then system use and information quality can influence each other or vice versa. Furthermore, system use and user satisfaction can affect the user satisfaction. Last system use and user satisfaction have strong correlation and reciprocal relationship to net benefit.

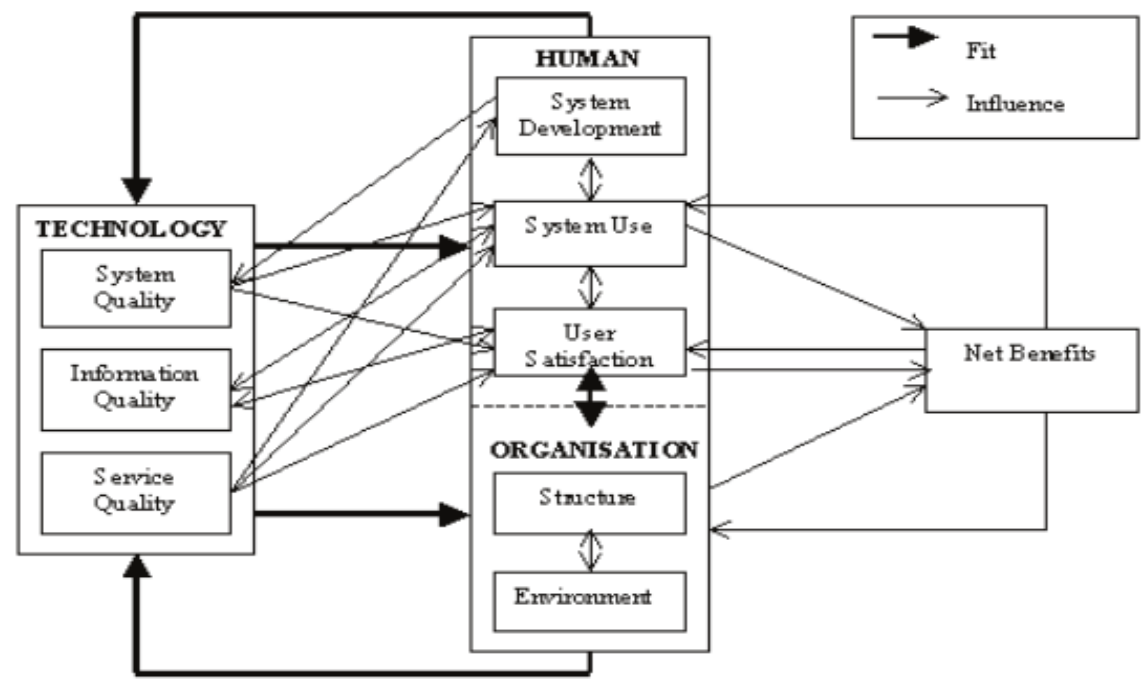

Figure 1 HOT-Fit frame work [1]

The HOT Fit model basically places the three main elements (Human, Organization, Technology) to be important in information systems, namely, people, organizations, and technology as well as the suitability of the relationship between the three variables. The HOT-fit framework can be used to identify processes and information needs in a service application. The framework provides comprehensive evaluation factors, complete dimensions to measure a service process, the main components of a system, development, use and usefulness. This allows it to be used as an ongoing evaluation of a system with other evaluation models.

This study is intended to describe the use of the HOT fit model in various evaluation practices that have been carried out on some article include in the research. The human, organizational and technological components make this evaluation model for use with various computerized programs with links to the policies of an organization or user or in this case a human component.

\section{RESULT AND DISCUSSION}

This research is a literature study involving 30 selected articles from various journals. Vulnerable when the published articles reviewed were in the period 2007 to 2020. Basically, the HOT Fit evaluation model is widely used in evaluations to evaluate health information systems. The step conducted in this literature review is by making code and labels for each article and engage the to the same major, method or problems that discussed.

Judging from the background the need for an evaluation model to evaluate Health Information Systems which intends to examine problems related to technology, organizations, and people to develop the system. At the beginning of its development, this model was issued as a research reference framework that integrated human, organizational, and technology components towards net benefits. The integration of each component is also important in the framework of this evaluation model, including human and organizational factors where these factors are the driving components that provide the decision that an 
information system in question will be implemented or not. In conclusion, human and organizational factors relate to technical problems that determine the effectiveness of the information system.

Various previous studies have analysed several relationships regarding the relationship between human, organizational and technological factors by adding various other variables that affect the effectiveness of the system in question. Some of these variables include the personal needs of related information systems such as individual, tools, structural process, machines and documents. As the background of this evaluation framework, DeLone and McLean's suggested the relationship between the success factors of information which includes six dimensions such as system quality which asses the information system process itself, information quality that asses the output of information systems, service quality that asses technical support, the use of information that involves the absorption of the output from the information system itself and net benefits as the overall effect of the information system. The series of factors is explained in the following chart.

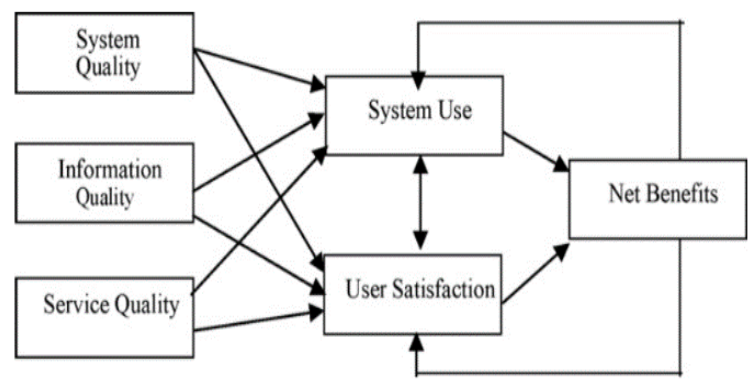

Figure 2 Information system success model [3] [4]

As an external series of success in an information system, there is also a linkage of external variables according to the IT-Organization Fit Model adapted from Scott Morton. The external variables include strategy, structure, information technology, roles and skills that influence the existence of the management process. This concept describes the interconnectedness of the factors that affect organizational balance, business strategy, which is formulated through common trends and changes in market, industry and technology. The model is described in the following chart.

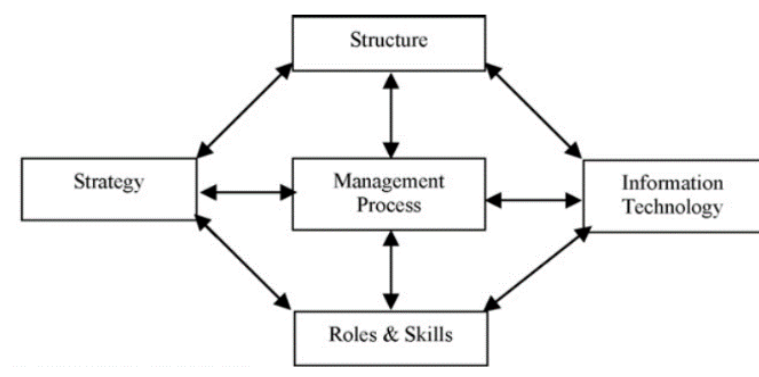

Figure 3 IT-organizational fit model [5]

Based on the analysis process literature review, it was found that the HOT-Fit model was widely used in the analysis of health information systems. Judging from the background, the HOT Fit framework of evaluation model is arranged which is intended to evaluate information systems in the health environment so that it is also used by several researchers in the health environment. Analysis of the sector scope of the use of this evaluation model in addition to the health environment is in the public service sector with a percentage of $16.6 \%$ which is followed by the use of this evaluation model in the financial sector. This is possible to apply to other sectors apart from the sector analysis in the table 1 .

The table show that the most common data analysis used in the study was descriptive statistic for over conducted by 9 articles and followed by Structural Equation Modelling (SEM) and Qualitative data analysis respectively. Every data analysis must be compatible to the data gained. There are two major method in getting the research data in the article that were being studied, that are survey and interview, other data gained or method such us observation and documentation were also conducted but not rather significant that the biggest two. The correlation of the data analysis and the research method show that the most common research method that used was survey or by spread the questionnaires. The surveys data were sufficient to quantitative data analysis such as SEM, regression, and descriptive. While the other research method thus was interviews often used to the qualitative analysis. The evidence of the diagram showed by the graph below.

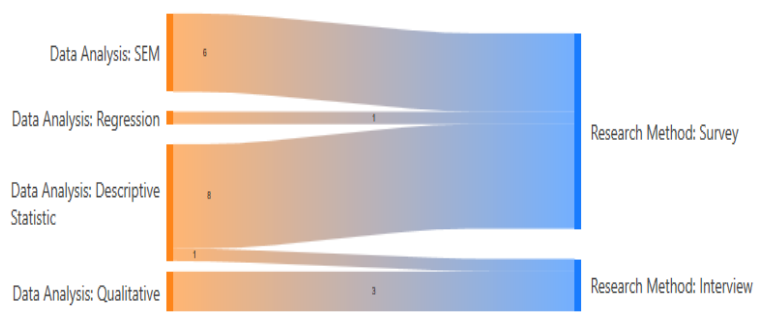

Figure 4 Data analysis and research method scheme 
Table 1. HOT-Fit article's sector

\begin{tabular}{|c|c|c|c|c|}
\hline No. & Sector & Author & Total & Precentage \\
\hline 1. & Health & $\begin{array}{l}\text { A Deharja and MW Santi (2018) [7], A Fauzan and Noviandi } \\
\text { (2019) [8], AD Putra, MS Dangnga, M Majid (2020) [9], A } \\
\text { Bayu, I Muhimah (2013) [10], A Sholistiyawati, A Mawarni, Y } \\
\text { Dhawmawan (2020) [11], Ariawan, Basuki, R Hidayat (2011) } \\
\text { [12], A Pratiwi, R Sudjaswadi, and H Kusnanto (2012) [13], } \\
\text { BRD Fitriana, R Hidana, SK Parinduri (2020) [14], C Sukma, } \\
\text { I Budi (2017) [15], DRP Mudiono (2018) [16], D Makalaglag, } \\
\text { F Agushybana, and A Mawarni (2017) [11], FR Rumambi, S } \\
\text { Robo, C Amalia (2020), [17] }\end{array}$ & 12 & $40 \%$ \\
\hline 2. & Public Service & $\begin{array}{l}\text { BAK Tiko (2016) [18], A Damayanti, et all (2019) [19], D } \\
\text { Mustifa, A Setyanto, M, R Arief (2018) [20], EK Jaya, AD } \\
\text { Herlambang, and SH Wijoyo (2019) [21], H Sallehudin, et al } \\
\text { (2019)[22] }\end{array}$ & 5 & $16.6 \%$ \\
\hline 3. & Finance & $\begin{array}{l}\text { Artha EU, Medias F and ZB Pambuki (2020)[23], C Iswanaji } \\
\text { (2019) [24], EP Dugroho, CM Karyati (2018) [25], GI } \\
\text { Prabowo (2019)[26] }\end{array}$ & 4 & $13.3 \%$ \\
\hline 4. & $\begin{array}{l}\text { Library } \\
\text { Management }\end{array}$ & $\begin{array}{l}\text { Asnawi (2016) [27], AP Sari (2019) [28] , D Kristyanto } \\
(2014)[29]\end{array}$ & 3 & $10 \%$ \\
\hline 5. & $\begin{array}{l}\text { Educational } \\
\text { Practice }\end{array}$ & $\begin{array}{l}\text { A Jaya, I Hanafi, R Febriana (2020) [30], Alfina, R Irfan } \\
\text { (2020) [31], BA Sarwono, RI Rokmawati, NH Wardani } \\
\text { (2019) [32], }\end{array}$ & 3 & $10 \%$ \\
\hline 6. & $\begin{array}{l}\text { Educational } \\
\text { Management }\end{array}$ & $\begin{array}{l}\text { AH Mujianto, B Soedijono, Henderi (2017) [33], A Subagiyo, } \\
\text { E Nugroho (2012)[34] }\end{array}$ & 2 & $6.6 \%$ \\
\hline 7. & $\begin{array}{l}\text { Goverment } \\
\text { Management }\end{array}$ & AM Kusumawati and EH Fanida (2014) [35], & 1 & $3.3 \%$ \\
\hline
\end{tabular}

Every article has its own definition of the research aim. The HOT-Fit evaluation model was a model that developed to evaluate a program or system by integrating the human, organization and technology factor, but also in the advance use of the application in other field they are commonly to determine a certain case. The distribution of the research aim for each article showed by the table 2 .

Table 2. HOT-Fit articles' research aim

\begin{tabular}{|c|c|}
\hline Research Aim & Grounded \\
\hline To Determine & 19 \\
\hline To Evaluate & 11 \\
\hline
\end{tabular}

The co-occurrence of data analysis, that used by each article included in this analysis is shown at the data below (table 3 ).

Table 3. HOT-Fit articles' data analysis

\begin{tabular}{|c|c|}
\hline Data Analysis & Grounded \\
\hline Correlation & 1 \\
\hline Descriptive Statistic & 9 \\
\hline Qualitative & 5 \\
\hline Regression & 3 \\
\hline SEM & 6 \\
\hline Triangulation & 1 \\
\hline
\end{tabular}

\begin{tabular}{|l|c|}
\hline Others & 5 \\
\hline Total & 30 \\
\hline
\end{tabular}

Based on the data it can be reflected that most of the article are aim to determine the effectiveness of a program or a system, instead of evaluate them. Thus, because determination have the wider scope of expectation and discussion to the certain issued that been criticised. While the program objected for each article are showed through the table below.

Table 4. HOT-Fit articles' program

\begin{tabular}{|c|c|}
\hline Program & Grounded \\
\hline E-Goverment & 1 \\
\hline E-Learning & 2 \\
\hline Financial & 3 \\
\hline Library & 3 \\
\hline PADE & 1 \\
\hline PMB & 1 \\
\hline PPDB & 1 \\
\hline SAPK & 1 \\
\hline SIKDA & 1 \\
\hline SIMPUSTRONIK & 2 \\
\hline SIMRS & 8 \\
\hline WakafMu & 1 \\
\hline Others & 5 \\
\hline
\end{tabular}




\begin{tabular}{|c|c|}
\hline Total & 30 \\
\hline
\end{tabular}

The data showed that the most common program been evaluated by using the hot fit model are the SIMRS that have the strong correlation with health sector. Some other program was conducted too, this mean that the hot-fit evaluation model was also sufficient to evaluate other sector circumstances.

By using the help of Atlas.ti qualitative software program can be inferred the connection between each program and the research aim that being conducted. Thus, explanation can be figured out by the graph below. The common program in health sector that became the celebrity in this evaluation model that are SIMRS was conducted through two research aim that are evaluating them and find the determination of certain things that necessary.

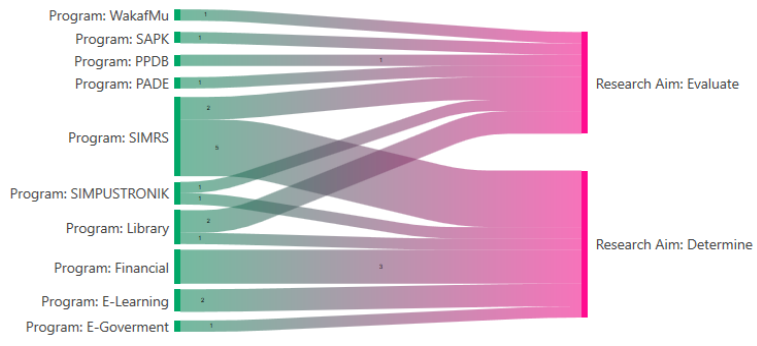

Figure 5 Program and research aim scheme

The use of technology in various sectors is also a challenge to widen the application of this evaluation model. This can also extend to its use in the field of education, both in the scope of education management and in the scope of education in practice in the field. Technological developments and their application in various sectors brought new problems and expanded the scope of the intended evaluation. Overall the components of this evaluation model are described as follows.

\subsection{Human}

The segments that are assessed through human factors in this assessment model are framework use, framework improvement, and client fulfilment. Framework use may comprise of the sum or term for instance requests, measure of interface time, number of capacities utilized, number of records got to, recurrence of access, and other relation and other factor linked. While client adapt to explicit capacities in general fulfilment, seen handiness, happiness, software satisfaction, decision making and other human stuff [6]

\subsection{Organization}

The organizational components involved in using this evaluation model are structure and environment. Structure consist of nature, culture, planning, strategy, management clinical process, communication, leadership, mediator and teamwork. While environment of the organization enhance with financing, government policy, political interest, localization, competition, inter-organizational relationship, population, and external communication [4].

\subsection{Technology}

The technology referred to in this case concerns problems regarding system quality, information quality, and service quality. The quality of the system measures the features that are integrated in an information system itself, including the performance of the system used in terms of its user components. As a further example, the quality of information is linked to the information generated by the information system which includes, for example, in the health information system, patient track records, reports, pictures, and initial information. Meanwhile, service quality is related to the overall support provided by the technology itself outside of the involvement of organizational policies or human factors.

Meanwhile, these three factors are aimed at the goal of their use and benefit which is called the net benefit. Clinical practice, performance, efficacy, consistency of decision-making, error reduction, clinical communication results and cos, are the final net profit components. $t$. Through a framework that is built by the relationship between the three components and one big component, this is used as an evaluation of the work system of the research being carried out.

\section{CONCLUSION}

On the basis of a comprehensive literature review, it can be concluded that in the health sector, including hospital information systems or other health-related systems, the use of the HOT match assessment model is most frequently used. In addition, the use of evaluation models in other sectors is still possible, such as in the public service sector, education at the management level or field practice, finance and so on. The most common research aim conducted to the article that used in the evaluation model is to determine the certain issues based on the necessity of the background. Therefore, this evaluation model can be an alternative choice for the evaluation process of a system that involves human, organizational, and 
technological components which are then reviewed through the benefits or net benefits obtained.

\section{AUTHORS' CONTRIBUTIONS}

W. P Hapsari design the study, executed the computational framework and directed the project. U.A. Labib and D. W. Safitri convinced the presented idea and verified the analytical method. Haryanto Haryanto supervised the project.

\section{ACKNOWLEDGMENTS}

The authors would like to thank the LPDP (Indonesian Endowment Fund) for giving the financial support and also thank the Department of Education of Research and Evaluation, Graduate School, Yogyakarta State University, which has supported and facilitated all the processes of research report.

\section{REFERENCES}

[1] M.M. Yusof, HOT-fit evaluation framework: validation using case studies and qualitative systematic review in health information systems evaluation adoption, in: Proceeding of the 5th European Conference on Information Management and Evaluation, vol. 5, Academic Conference Ltd., Reading South Oxfordshire, 2009, pp. 359-365.

[2] M.M. Sari, G.Y. Sanjaya, A. Meliala, Evaluasi sistem informasi manajemen rumah sakit (SIMRS) dengan kerangka HOT-FIT, in: Prosiding Seminar Nasional Sistem Informasi Indonesia, vol. 1, Departemen Sistem Informasi, ITS, Surabaya, 2016, pp. 204-207.

[3] W.H. DeLone, E.R. McLean, The DeLone and McLean Model of Information Systems Success: A Ten-Year Update, Journal of Management Information Systems 19(4) (2003) 9-30. DOI: https://doi.org/10.1080/07421222.2003.1104574 8

[4] M.M. Yusof, J. Kuljis, A. Papazafeiropoulou, L.K. Stergioulas, An Evaluation Framework for Health Information Systems: Human, Organization and Technology-Fit Factors (HOTFit ), International Journal of Medical Informatics 77(6) (2007) 386-398. DOI: https://doi.org/10.1016/j.ijmedinf.2007.08.011

[5] S. Morton, The Corporation of the 1990s: Information Technology and Organizational Transformation, Oxford University Press, 1991.
[6] M.M. Yusof, A.Y.A. Yusuff, Evaluating EGovernment System Effectiveness Using an Integrated Socio-Technical and Fit Approach, Information Technology Journal 12(5) (2013) 894-906.

DOI: https://doi.org/10.3923/itj.2013.894.906

[7] A. Deharja, M.W. Santi, The evaluation of hospital information system management based on hot-fit model at RSU Dr. H. Koesnadi Bondowoso 2018, in: Proceeding of the 1st International Conference on Food and Agriculture, vol. 1, Politeknik Negeri Jember, Jember, 2018, pp. 486-490.

[8] A. Fauzan, N. Noviandi, Evaluation Of Optima Regional Health Information System With HotFit on Technology Aspects Approach in Johar Baru Health Center Jakarta, Journal Intelligent Computing and Health Informatics 1(1) (2020) 17. DOI: https:/doi.org/10.26714/jichi.v1i1.5397

[9] A.D. Putra, M.S. Dangnga, M. Majid, Evaluasi Sistem Informasi Manajemen Rumah Sakit (SIMRS) dengan Metode Hot Fit di RSUD Andi Makkasau Kota Parepare, Jurnal Ilmu Manusia dan Kesehatan 1(1) (2020) 61-68. DOI: https://doi.org/10.31850/makes.v3i1.294

[10] A. Bayu, S. Izzati, Evaluasi Faktor-faktor kesuksesan implementasi sistem informasi manajemen Rumah Sakit di PKU Muhammadiyah Sruweng dengan menggunakan metode HOT-fit, in: Prosiding Seminar Nasional Informatika Medis, vol. 1, Universitas Islam Indonesia, Sleman, 2013, pp. 78-86.

[11] D. Makalalag, F. Agushybana, A. Mawarni, Evaluasi Sistem Informasi Pelayanan Rekam Medis di RSJ Prof. Dr. V. L. Ratumbuysang Provinsi Sulawesi Utara dengan Pendekatan Hot Fit Model, Jurnal Manajemen Kesehatan Indonesia 5(2) (2017) 82-93. DOI: https://doi.org/10.14710/jmki.5.2.2017.82-93

[12] A. Basuki, Evaluasi penerapan sistem informasi puskesmas elektronik (simpustronik) di Dinas Kesehatan Kabupaten Bondowoso menggunakan metode HOT (human, organization, technology) FIT, M.E. thesis, Department of Electrical Engineering and Information Technology, Universitas Gadjah Mada, Yogyakarta, 2011.

[13] A. Pratiwi, R. Sudjaswadi, H. Kusnanto, Analisis penerapan sistem informasi manajemen farmasi di Rumah Sakit Mata dr. Yap Yogyakarta dengan 
HOT-FIT model, Jurnal Manajemen dan Pelayanan Farmasi 2(1) (2016) 45-49.

[14] B. Rizki, D. Fitriana, R. Hidana, S.K. Parinduri, Analisis Penerapan Sistem Informasi Manajemen Puskesmas (Simpus) dengan Model Human Organization Technology (HOT)-Fit di Puskesmas Tanah Sareal Kota Bogor Tahun 2019 Pendahuluan Metode, PROMOTOR: Jurnal Mahasiswa Kesehatan Masyarakat 3(1) (2020) 18-27.

[15] C. Sukma, I. Budi, Penerapan Metode HOT Fit dalam Evaluasi Sistem Informasi Manajemen Rumah Sakit di RSUD Jombang, Jurnal Informasi dan Komputer 5(1) (2017) 34-41. DOI: https://doi.org/10.35959/jik.v5i1.94

[16] D. Mudiono, Analisis penerapan sistem informasi manajemen rumah sakit dengan model human organization technology (HOT)-Fit di RSU Dr. H. Koesnadi Bondowoso, M.Sc. thesis, Sciences of Health, Program Pascasarjana, Universitas Negeri Jember, Jember, 2018.

[17] F.R. Rumambi, S. Robo, C. Amalia, Identifikasi Dampak Penggunaan Sistem Informasi Rumah Sakit (SIRS) Terhadap Pelayanan Kesehatan Menggunakan Hot-Fit Model 2006, Jurnal Media Informatika Budidarma 4(1) (2020) 216. DOI: https://doi.org/10.30865/mib.v4i1.1973

[18] B.A.K. Tiko, Evaluasi Sistem Informasi Pengelolaan Administrasi Desa Elektronik (Pade) Pada Kantor Desa Brengkok Kabupaten Lamongan Menggunakan Human Organization Technology (Hot) Fit Model, S.Sc. thesis, Fakultas Ilmu Komputer, Universitas Brawijaya, 2016.

[19] A. Damayanti, et al., Performance of management information system of engineering faculty internship office UNNES 2018 evaluation with HOT Fit models, in: Journal of Physics: Conference Series, vol. 1444, IOP Publishing, Bristol, 2020, pp. 1-6. DOI: https://doi.org/10.1088/1742$\underline{6596 / 1444 / 1 / 012038}$

[20] D. Mustofa, A. Setyanto, M.R. Arief, Analisis Kualitas Sistem Berdasarkan Persepsi Pengguna Pada Website www. amikompurwokerto. ac. id Menggunakan HOT FIT Model, Jurnal Ilmiah IT CIDA 4(2) (2019) 25-32.

[21] E.K. Jaya, A.D. Herlambang, S.H. Wijoyo, Evaluasi Kualitas Layanan Website Dinas
Pariwisata Kabupaten Banyuwangi Dengan Metode e-Govqual, Human Organization Technology (HOT) Fit dan Kano Model, Pengembangan Teknologi Informasi dan Ilmu Komputer 3(4) (2019) 3608-3616.

[22] H. Sallehudin, N. Safie, M. Satar, Modelling the Enterprise Architecture Implementation in the Public Sector using HOT-Fit Framework, International Journal of Advanced Computer Science and Application 10(8) (2019) 191-198. DOI:

https://doi.org/10.14569/IJACSA.2019.0100825

[23] E.U. Artha, F. Medias, Z.B. Pambuko, Evaluation of wakafMu fundraising platform using HOTFIT method, in: Journal of Physics: Conference Series, vol. 1517, IOP Publishing, Bristol, 2020, pp. 1-7. DOI:. https://doi.org/10.1088/1742$\underline{6596 / 1517 / 1 / 012095}$

[24] C. Iswanaji, Analysis of Accounting Information System Using Hot Fit Model Method in Indonesia Islamic Micro Financial Institutions, Applied Finance and Accounting 5(2) (2019) 1. DOI: https://doi.org/10.11114/afa.v5i2.4172

[25] E.P. Nugroho, C.M. Karyati, Analysis of Use EFiling Information System Directorate General of Tax Using HOT Fit Method on Human Variables, International Journal of Computer Science and Software Engineering 7(10) (2018) 229-236.

[26] G.I. Prabowo, Evaluasi Keberhasilan Implementasi Sistem Informasi E-Donasi dengan Metode Hot-Fit (Studi Kasus: Direktorat Ekz Laznas Inisiatif Zakat Indonesia), M.Sc. thesis, Fakultas Sains dan Teknologi, Universitas Islam Negeri Syarif Hidayatullah, Jakarta, 2019.

[27] Asnawi, Evaluasi Implementasi Sistem Informasi SENAYAN Library Management System (SLIMS) di Perpustakaan Universitas Syiah Kuala Dengan Menggunakan Human Organization Technology (HOT) Fit Model, M.S. thesis, Ilmu Perpustakaan, Universitas Islam Negeri Sunan Kalijaga, Yogyakarta, 2016.

[28] A.P. Sari, Pengukuran Keberhasilan Penerapan Sistem Institutional Repository Di UIN Syarif Hidayatullah Jakarta Menggunakan Human Organization Technology (HOT) Fit Model, S.Sc. thesis, Fakultas Sains dan Teknologi, Universitas Islam Negeri Syarif Hidayatullah, Jakarta, 2019. 
[29] D. Kristyanto, Pengaruh Human Organization Technology (HOT) Fit Model Terhadap Pemanfaatan Sistem Informasi Di Perpustakaan Universitas Airlangga Surabaya, M.S. thesis, Ilmu Perpustakaan dan Informasi, Universitas Islam Negeri Sunan Kalijaga, Yogyakarta, 2016.

[30] A. Jaya, I. Hanafi, R. Febriana, Evaluation of ELearning Implementation using HOT Fit Model in State Vocational High School , Jakarta, International Journal of Educational Research 8(1) (2020) 147-156.

[31] A. Alfina, R. Irfan, Analysis of e-learning implementation using human organization technology approach (HOT) fit models, J. in: Journal of Physics: Conference Series, vol. 1456, IOP Publishing, Bristol, 2020, DOI: https://doi.org/10.1088/17426596/1456/1/012058

[32] B.A. Sarwono, R.I. Rokmawati, N.H. Wardani, Evaluasi Kualitas dan Kesuksesan Implementasi E-Learning Fakultas Ilmu Komputer Menggunakan Model Unified Theory of Acceptance And Use Of Technology, Model Delone \& Mclean dan Hot Fit Terintegrasi, Jurnal Pengembangan Teknologi Informasi dan Ilmu Komputer 3(5) (2019) 5193-5200.

[33] A. Heru and B. Soedijono, Pengukuran Tingkat Kesuksesan Penerapan Website Penerimaan Mahasiswa Baru ( PMB ) Online di Perguruan Tinggi Swasta Dengan Pendekatan Human Organization Technology ( HOT ) Fit Model, Jurnal Ilmiah Teknologi Sistem Informasi 3(1) (2017) 24-33.

[34] A. Subagiyo, Penggunaan Metode HOT-Fit Dalam Evaluasi Keberhasilan Implementasi Sistem Informasi: Studi Kasus Sistem Informasi Penerimaan Peserta Didik Baru (PPDB) Online Kota Yogyakarta, M.S. thesis, Teknik Informasi, Universitas Negeri Gadjah Mada, Yogyakarta, 2011.

[35] A.M. Kusumawati, E.H. Fanida, Evaluasi Sistem Aplikasi Pelayanan Kepegawaian (SAPK) melalui HOT-Fit Model di Kantor Regional II Badan Kepegawaian Negara Surabaya, Publika UNESA 2(1) (2014) 1-10. 